\title{
Health Locus Of Control pada Perawat yang Merokok dan yang Tidak Merokok
}

\section{Health Locus of Control on Nurses Who Smoke and Who Do \\ Not Smoke}

\author{
Putri Mandasari Dwi Jayanti, Rina Rahmatika \\ Fakultas Psikologi Universitas YARSI \\ Email:putrimandasaridj@gmail.com,rina.rahmatika@gmail.com
}

KATA health locus of control, perawat, perilaku merokok.

KUNCI

KEYWORDS health locus of control, nurse, smoking behavior

ABSTRAK Perawat sebagai tenaga kesehatan diharapkan memiliki perilaku yang sehat, namun masih terdapat pula perawat yang merokok. Merokok atau tidak merokok pada perawat terkait dengan bagaimana keyakinan akan pihak yang mengontrol kesehatan diri mereka, atau biasa disebut sebagai health locus of control. Tujuan dari penelitian ini adalah peneliti ingin melihat perbedaan health locus of control antara perawat yang merokok dengan yang tidak merokok. Subjek penelitian adalah 92 perawat di Jakarta dengan rentang usia 21-30 tahun, diperoleh dengan metode incidental sampling. Alat ukur yang digunakan untuk mengukur health locus of control adalah Multidimentional Health Locus of Control Form $A$. Hasil penelitian menunjukkan bahwa terdapat perbedaan pada dimensi chance dalam health locus of control pada perawat yang merokok dan tidak merokok dengan nilai $\mathrm{t}=2,691(\mathrm{p}=0,009>0,05)$, artinya perawat yang merokok lebih memiliki keyakinan bahwa kesehatannya dipengaruhi oleh keberuntungan atau takdir dibandingkan dengan perawat non perokok, sedangkan pada dimensi internal dan powerful others tidak terdapat perbedaan pada perawat yang merokok dan tidak merokok. 
ABSTRACT As health practitionaires, nurses are expected to have healthy behavior, however there are nurses who are smoking. Smoking behavior on nurses is related to how they believe in which aspects that control their health, or used to be called health locus of control. Purpose of this study is to investigate differences of health locus of control between nurses who smoke and who do not. The sample is 92 nurses whose age are 21-30 years old and located in Jakarta. Multidimentional Health Locus of Control Form A is used to measure health locus of control. Result of this study shows that there is a difference in the chance dimension of health locus of control between nurses who smoke and who do not $(t=2.691 ; p$ $=0.009>0,05)$. The result indicate that nurses who smoke had a higher belief that their health are influenced by luck or destiny compared with non-smoking nurse, while internal dimension and powerful others show no differences between nurse who smoke and who do not.

\section{PENDAHULUAN}

Perilaku merokok sudah menjadi hal yang wajar bagi umat manusia. Hal ini dikarenakan individu yang merokok dianggap sebagai life style terkini dan dapat mengurangi stres (Anas, 2016). Berdasarkan riset Atlas Tobacco pada tahun 2015 Indonesia menjadi negara yang memiliki jumlah perokok terbanyak diantara negara-negara di dunia (Ratna, 2016). Pada tahun 2017, sekitar 58,8\% atau 235 ribu penduduk Indonesia merupakan perokok aktif (Simanjuntak, 2015).

Perilaku merokok ini sudah terbukti dapat menyebabkan penyakit kanker paruparu, jantung, resiko kelahiran prematur, stroke, sampai terjadinya kematian (Nururrahmah, 2014). Hal tersebut dikarenakan pada satu batang rokok mengandung ribuan zat berbahaya (Perdana, 2016). Menurut Putri (2015), setiap tahunnya merokok dianggap sebagai penyebab kematian tertinggi bila dibandingkan dengan kematian yang terjadi akibat bencana alam. Sekitar $90 \%$ kematian akibat kanker paru-paru disebabkan oleh perilaku merokok, baik sebagai perokok aktif maupun sebagai perokok pasif (Kristianti, 2014).

Salah satu area bebas rokok adalah rumah sakit (Rosy \& Esa, 2015). Meski demikian, aturan tersebut cenderung diabaikan oleh masyarakat umum serta pegawai rumah sakit, salah satunya adalah perawat (Hapsari, 2013). Perawat merupakan salah satu profesi yang menjadi indikator utama dalam rumah sakit (Sari, Dewi, \& Utami, 2014). Hal tersebut dikarenakan perawat dianggap perlu untuk menjaga kesehatannya karena ia memiliki peran yang besar terhadap kesehatan pasien, dan yang paling sering berinteraksi dengan pasien dibandingkan tenaga kesehatan lainnya (Hapsari, 2013). WHO berkomitmen menjadikan perawat sebagai role model bagi para pasien untuk menjaga kesehatannya (Jati, 2015).

Salah satu kepala perawat di RSAU menyatakan bahwa sekitar $65 \%$ perawat merupakan perokok aktif (Yunita, 2009). Hasil survei lainnya di RSUD Jambi memperlihatkan sekitar $94 \%$ tenaga kesehatan laki-laki termasuk perawat memiliki kebiasaan merokok (Daroji, Prabandari, \& Paramastri, 2011). Apabila dibandingkan dengan profesi lain yang ada di dalam rumah sakit, perawat perokok memiliki persentase yang lebih tinggi, yaitu sekitar 35\% (Pramudiarja, 2012).

Penyebab dari perilaku merokok pada perawat ini dikarenakan tekanan yang didapatkan dari tempat kerjanya. Hal ini sejalan dengan penelitian yang dilakukan oleh Daroji dkk (2011) bahwa sekitar 94\% tenaga kesehatan termasuk perawat yang 
bekerja di rumah sakit memiliki kebiasaan merokok ditempat kerja

Meskipun perilaku merokok di kalangan perawat cukup tinggi, terdapat sebagian perawat yang memilih untuk tidak merokok. Salah satu alasan perawat untuk tidak merokok adalah kebijakan pemerintah yang melarang individu perokok untuk menjadi tenaga kesehatan yang bertanggung jawab dalam membentuk perilaku sehat pada masyarakat (Saptono, 2011). Sekitar 80\% perawat sudah berhasil untuk berhenti merokok. Alasan yang didapatkan adalah mereka merasa bersalah dan malu karena profesi mereka adalah profesi yang memegang peranan penting dalam menjaga kesehatan para pasiennya (Hapsari, 2013).

Perilaku merokok dan tidak merokok pada perawat dapat disebabkan oleh keyakinan individu terhadap kemampuannya dalam mengontrol kesehatan diri atau health locus of control (HLoC). Menurut Wallston, Wallston dan Devellis (1994), health locus of control adalah suatu keyakinan bahwa kesehatan seseorang dikendalikan oleh faktor eksternal atau faktor internal. Menurut Wallston, Wallston dan Devellis (1994), HLoC adalah suatu keyakinan individu bahwa kesehatan dirinya merupakan hasil dari tindakannya sendiri (internal), individu juga percaya ia dapat mengendalikan dan mengubah lingkungan, atau dapat melakukan kontrol terhadap nasibnya sendiri. Sebaliknya, ada pula individu yang memiliki keyakinan bahwa kesehatan yang dimiliki adalah hasil pengaruh lingkungan dan pengaruh orang lain (powerful others) atau dipengaruhi oleh keberuntungan atau nasib (chance) sehingga individu tersebut cenderung pasif dalam menghadapi hal-hal yang terjadi pada dirinya (Wallston, Wallston \& Devellis, 1994).

Penelitian Chotidjah (2012)

menemukan bahwa pengetahuan tentang dampak merokok bukan satu-satunya faktor yang mempengaruhi perilaku merokok. Faktor eksternal seperti pengaruh teman dan media massa dapat mempengaruhi individu untuk merokok. Penelitian lainnya yang dilakukan oleh Eiser, Eiser, Gammage dan Morgan (1989) juga memperlihatkan bahwa individu yang merokok memiliki chance health locus of control lebih tinggi daripada individu yang tidak merokok. Lebih jauh, penelitian Mandasari (2012) juga menyatakan bahwa individu yang merokok memiliki skor yang tinggi pada dimensi powerful others dan chance health locus of control. Dari hasil diatas dapat diartikan bahwa orang lain atau keberuntungan atau factor eksternal memiliki kontrol yang besar terhadap pengambilan keputusan individu dalam menjaga kesehatannya.

Jika dilihat dari segi budaya, HLoC pada setiap budaya berbeda-beda. Pada budaya Barat individu cenderung memiliki HLoC internal, dikarenakan individu pada budaya Barat memiliki sifat individualis dan sangat jarang menjalin hubungan dengan orang lain (Santrock, 2003), sehingga mereka meyakini bahwa kontrol terhadap kesehatan ada pada dirinya sendiri. Hal ini sejalan dengan penelitian yang dilakukan oleh Bennet, Moore, Norman, Murphy dan Smith (1997) menemukan bahwa perokok aktif memiliki HLoC internal yang tinggi dibandingkan dengan mereka yang tidak merokok. Individu tersebut percaya bahwa perilakunya ditentukan oleh dirinya sendiri, dan akan berdampak pada dirinya sendiri pula.

Berkebalikan dengan budaya barat, pada budaya timur individu cenderung memiliki HLoC eksternal. Hal ini dikarenakan individu pada budaya Timur memiliki sifat kolektivistik yang memiliki orientasi pada suatu kelompok (Santrock, 2003), oleh karena itu mereka cenderung meyakini bahwa orang lain juga dapat mempengaruhi kontrol terhadap kesehatannya. Penelitian yang dilakukan oleh Rahmatika (2017) menunjukkan di Indonesia individu yang merokok lebih meyakini bahwa faktor eksternal merupakan salah satu faktor yang dapat 
mempengaruhi perilaku sehatnya, sehingga mereka cenderung kurang memperhatikan perilaku sehat dengan cara tetap merokok. Temuan ini juga sesuai didalam literatur Barat bahwa pada budaya Timur individu tersebut cenderung memiliki keyakinan terhadap HLoC eksternal, baik powerful others atau chance (Wallston \& Wallston, 1982).

Perilaku sehat pada perawat akan berkontribusi pada kesehatan masyarakat baik secara langsung ataupun tidak langsung. Dengan memiliki perilaku sehat maka perawat akan dapat dijadikan panutan bagu masyarakat untuk memiliki perilaku sehat pula. Selain itu, apabila perawat memiliki perilaku sehat maka ia akan menjadi agen perubahan untuk memberikan program promosi ataupun prevensi bagi masyarakat secara umum, khususnya terkait perilaku merokok. Tekait dengan hal tersebut, perlu diketahui bagaimana keyakinan perawat dengan pihak yang mengontrol perilaku merokoknya, apakah internal atau eksternal, dalam konteks perilaku merokok. Berdasarkan penjabaran di atas, peneliti tertarik untuk mengetahui perbedaan health locus of control pada perawat yang merokok dan yang tidak merokok karena penelitian yang mengulas tentang perilaku merokok pada tenaga kesehatan masih terbatas di Indonesia.

\section{METODE PENELITIAN Identifikasi Variabel}

Variabel penelitian ini adalah health locus of control.

\section{Subjek Penelitian}

Teknik sampling dalam penelitian adalah incidental sampling. Subjek dalam penelitian ini berjumlah 92 partisipan yang terdiri dari 41 perawat merokok dan 51 perawat tidak merokok, yang berdomisili di wilayah DKI Jakarta dengan rentang usia 21-30 tahun.

\section{Instrumen Penelitian}

Instrumen penelitian yang digunakan dalam penelitian ini adalah Multidimensional Health Locus of Control Form A. Dalam penelitian ini, kuesioner berjumlah 18 aitem dengan koefisien reliabilitas pada masing-masing dimensi $>0,6$.

\section{Metode Analisis Statistik}

\section{Uji Normalitas}

Pada penelitian ini, untuk melakukan uji normalitas peneliti menggunakan Kolmogorov-Smirnov test dengan nilai signifikansi $>0,05$.

2.

Uji Hipotesis

Metode yang digunakan dalam penelitian ini adalah pengujian hipotesis komparatif dengan teknik statistik T-test.

\section{ANALISIS DAN HASIL \\ Deskripsi Subjek Penelitian}

Perawat perokok dalam penelitian ini berjumlah 41 partisipan dengan berjenis kelamin laki-laki sebanyak 37 partisipan dan perempuan sebanyak empat partisipan, dengan nilai rata-rata pada usia sebesar $(M=25,59), \quad(S D=3,248)$. Setiap harinya partisipan dalam penelitian ini konsumsi rokok sebanyak $1-10$ batang $(76 \%)$, dan sudah menjadi perokok selama $>7$ Tahun (37\%). Mayoritas partisipan dalam penelitian ini memiliki teman yang samasama menjadi perokok (73\%), serta pernah mengalami gangguan pusing/sakit kepala $(44 \%)$. Data tentang perawat yang tidak merokok dalam penelitian ini berjumlah 51 partisipan, berjenis kelamin laki-laki (80\%) dan perempuan (20\%), dengan ratarata usia $(\mathrm{M}=24,82), \quad(\mathrm{SD}=3,809)$. Berdasarkan 27 perawat non perokok, mayoritas dari mereka memiliki teman dan anggota keluarga perokok (48\%) dan pernah mengalami gangguan pusing/sakit kepala (62\%).

\section{Kategorisasi Health Locus of Control Pada Perawat Merokok dan Tidak Merokok}


Penggolongan partisipan dalam penelitian ini dijabarkan ke dalam 5 kategorisasi, yaitu sangat rendah, rendah, sedang, tinggi, sangat tinggi. Mayoritas partisipan penelitian dalam dimensi internal, chance, dan powerful others dalam HLoC berada pada kategorisasi sedang.

\section{Uji Normalitas}

Tabel 1

\section{Uji Normalitas}

\begin{tabular}{ccccccc}
\hline & \multicolumn{2}{c}{ Internal } & \multicolumn{2}{c}{ Chance } & \multicolumn{2}{c}{ Powerful Others } \\
\cline { 2 - 7 } & Perokok & $\begin{array}{c}\text { Non } \\
\text { Perokok }\end{array}$ & Perokok & $\begin{array}{c}\text { Non } \\
\text { Perokok }\end{array}$ & Perokok & $\begin{array}{c}\text { Non } \\
\text { Perokok }\end{array}$ \\
\cline { 2 - 7 } Swekness &,- 228 &, 342 &, 075 &, 307 &, 440 &, 440 \\
SE Swekness &, 369 &, 333 &, 369 &, 333 &, 369 &, 333 \\
$Z$ & $-0,61$ & 1,02 & 0,20 & 0,92 & 1,19 & 1,32 \\
Kurtosis & 1,283 &,- 417 &,- 330 & 1,177 &,- 069 &,- 615 \\
SE Kurtosis &, 724 &, 656 &, 724 &, 656 &, 724 &, 656 \\
$Z$ & 1,77 & $-0,22$ & $-0,45$ & 1,79 & $-0,09$ & $-0,9$ \\
\hline
\end{tabular}

Berdasarkan tabel diatas dapat diketahui bahwa nilai $\mathrm{Z}$ yang didapatkan pada dimensi internal, chance, dan powerful others adalah $\mathrm{Z}<1,96$ yang berarti dalam dimensi internal, chance, dan powerful others pada perokok dan non perokok berdistribusi normal.

\section{Uji Hipotesis}

Tabel 2

Uji Hipotesis

\begin{tabular}{ccclc}
\hline Dimensi & T & Sig. (2-tailed) & \multicolumn{1}{c}{ Perawat } & Mean \\
\hline \multirow{2}{*}{ Internal } & \multirow{2}{*}{0,546} & 0,586 & Merokok & 5,13 \\
& & & Tidak Merokok & 5,09 \\
Chance & \multirow{2}{*}{2,691} & 0,009 & Merokok & 3,74 \\
& \multirow{2}{*}{ Powerful Others } & \multirow{2}{*}{0,512} & Tidak Merokok & 3,25 \\
& & \multirow{2}{*}{0,134} & Merokok & 4,02 \\
& & & Tidak Merokok & 3,77 \\
\hline
\end{tabular}

Berdasarkan hasil dari uji komparasi dengan menggunakan metode Independent Sample T-test, ditemukan tidak ada perbedaan pada dimensi internal antara dua kelompok perawat $t=0,546, p=0,586$ $(>0,05)$. Hal yang sama juga ditemukan pada dimensi powerful others $t=1,512, p$ $=0,134(>0,05)$. Dengan demikian Ha
Ditolak dan Ho Diterima, hal ini dapat diartikan bahwa tidak terdapat perbedaan pada dimensi internal dan powerful others dalam health locus of control yang signifikan pada perawat yang merokok dan yang tidak merokok. Sedangkan pada dimensi chance antara dua kelompok memiliki skor $t=2,691, p=0,009(<0,05)$, sehingga dapat di katakan bahwa Ha 
Diterima dan Ho Ditolak, artinya terdapat perbedaan yang signifikan dalam dimensi chance pada perawat yang merokok dan tidak merokok.

\section{Analisis Tambahan: Uji Beda Berdasarkan Demografi}

Peneliti melakukan analisa tambahan untuk mengetahui apakah terdapat perbedaan tingkat resiliensi keluarga ditinjau dari faktor-faktor demografi. Hasil yang didapatkan adalah pada dimensi internal memiliki perbedaan pada data demografis terkait dengan pihak yang merokok. Hal ini dikarenakan nilai signifikansi yang didapatkan adalah $(p=0,033<0,05)$. Sedangkan pada dimensi chance memiliki perbedaan pada data demografis terkait dengan jenis kelamin yang mendapatkan nilai signifikansi $(p=0,003<0,05)$. Kemudian untuk dimensi powerful others tidak memiliki perbedaan pada tiap data demografis.

\section{DISKUSI}

Berdasarkan hasil analisis data, dapat diketahui bahwa pada dimensi chance mendapatkan hasil $t=2,691, p=$ $0,009(p>0,05)$ yang menunjukkan bahwa Ha Diterima dan Ho Ditolak. Artinya, terdapat perbedaan HLoC chance pada perawat yang merokok dan tidak merokok. Hal ini menunjukkan bahwa perawat yang merokok dan tidak merokok memiliki perbedaan keyakinan tentang kesehatan dirinya dipengaruhi oleh keberuntungan atau takdir. Skor mean dalam dimensi chance pada perawat yang merokok lebih tinggi $(M=3,74)$ daripada perawat yang tidak merokok $(M=3,25)$. Hal ini sejalan dengan penelitian Eiser dkk (1989) bahwa perawat perokok memiliki skor yang lebih tinggi pada dimensi chance daripada yang bukan perokok. Dapat disimpulkan bahwa perawat yang merokok lebih mempercayai takdir atau keberuntungan dalam mengontrol kesehatannya.

Sejalan pula dengan penelitian Wallston dkk (1982) bahwa individu yang tidak berperilaku sehat cenderung berorientasi pada HLoC chance. Dimensi chance ini sering sekali dikaitkan dengan tingkat religiusitas individu dalam meyakini kontrol diri terhadap kesehatan, sehingga tidak sedikit masyarakat Indonesia mengkaitkan antara takdir Tuhan dan kesehatan dirinya (Arifin \& Rahayu, 2012). Misalnya, saat individu sedang terkena penyakit, mereka akan cenderung mengabaikan penyakit tersebut dengan terus menerus berperilaku tidak sehat karena sakit atau sehatnya individu sudah ditakdirkan oleh Tuhan. Hal ini dibuktikan dengan data demografis pada perawat yang merokok bahwa mereka pernah mengalami gangguan sakit kepala dan gangguan pernafasan, namun mereka masih tetap melakukan perilaku merokok.

Selain dikaitkan dengan religiusitas individu, chance juga sering dikaitkan dengan sebuah keberuntungan dan peluang. Dalam penelitian ini perawat perokok yang tidak mengalami gangguan penyakit juga tidak sedikit, tidak mengalami dampak dari merokok membuat mereka beranggapan bahwa sakit atau tidak sakitnya seseorang adalah sebuah keberuntungan pula. Hal inilah yang membuat mereka memilih untuk tetap menjadi perokok. Mereka juga menganggap bahwa peluang untuk mereka merokok sangat besar, hal ini dibuktikan dengan penelitian Yunita (2009) bahwa sekitar $65 \%$ perawat adalah perkokok artinya walaupun mereka sudah diketahui sebagai perokok, mereka masih dapat bekerja sebagai perawat sehingga para perawat tersebut masih mendapatkan penghasilan untuk membeli rokok tersebut.

Pada dimensi chance, individu tidak merokok dapat dikarenakan nilainilai keyakinan yang ada dalam masyarakat seperti norma budaya dan agama sehingga hal ini yang membuat mereka memutuskan untuk tidak merokok. Nilai-nilai yang ada dalam masyarakat adalah dengan menjadikan perawat sebagai panutan atau role model dalam menjaga kesehatannya (Jati, 2015). Individu yang berorientasi pada dimensi ini juga lebih 
meyakini bahwa dengan adanya takdir Tuhan yang mempengaruhi kesehatannya, mereka dapat mengubah takdir tersebut dengan berperilaku sehat seperti tidak merokok.

Pada dimensi internal tidak menunjukkan perbedaan antara perawat yang merokok dan tidak merokok atau Ha Ditolak dan Ho Diterima. Artinya, perawat yang merokok dan tidak merokok sama-sama memiliki keyakinan bahwa dirinya dapat mengontrol kesehatannya, atau sama-sama tidak memiliki keyakinan bahwa dirinya dapat mengontrol kesehatannya. Hasil penelitian ini berbeda dengan penelitian yang dilakukan oleh Bennet dkk (1997) bahwa individu yang tidak merokok mendapatkan nilai yang lebih tinggi pada dimensi internal dan menganggap bahwa kontrol terhadap kesehatan dikendalikan oleh dirinya sendiri sehingga akan menerapkan perilaku sehat. Meski demikian, pada penelitian yang dilakukan oleh Mandasari (2012) individu yang merokok justru memiliki internal yang tinggi karena walaupun status mereka sebagai perokok, mereka juga dapat menjaga kesehatannya, misalnya dengan cara berolahraga.

Dari perbedaan hasil penelitian di atas dapat disimpulkan bahwa perawat yang merokok dan tidak merokok tidak memiliki perbedaan terkait dengan keyakinan diri terhadap kontrol kesehatannya. Hasil penelitian ini didukung oleh kategorisasi skor perawat yang merokok dan tidak merokok, dimana dalam dimensi internal health locus of control berada dalam kategori sedang. Artinya, perawat yang merokok dan tidak merokok merasa bahwa dirinya adalah pihak yang dapat mengontrol kesehatannya, namun tidak terlalu baik dan kemungkinan memiliki faktor yang lebih mengontrol kesehatannya. Hal ini dibuktikan dengan berdasarkan data demografis dalam penelitian bahwa perawat yang tidak merokok masih tetap berada di sekitar perokok, walaupun mereka sudah mengetahui dampak dari menjadi perokok pasif.

Dimensi powerful others tidak menunjukkan perbedaan antara perawat yang merokok dan tidak merokok. Hasil ini memiliki arti bahwa tidak terdapat perbedaan yang signifikan antara perawat yang merokok dan tidak merokok. Tidak adanya perbedaan dalam dimensi ini kemungkinan terjadi karena besarnya pengaruh dari lingkungan sosialnya, bahwa perawat yang merokok cenderung meyakini bahwa dukungan dari orang lain atau pihak yang ada disekitarnya dapat mempengaruhi kontrol terhadap kesehatannya (Lavental \& Clearly, 1995).

Jika dilihat dari kategorisasi yang dilakukan oleh peneliti dalam dimensi powerful others, dimensi ini berada pada kategori sedang. Artinya, perawat yang merokok dan tidak merokok memiliki keyakinan bahwa orang lain juga berpengaruh terhadap kesehatannya, namun kemungkinan terdapat faktor lain yang dapat mempengaruhinya. Hal ini dibuktikan dengan adanya data demografis tentang jumlah partisipan yang berada didekat perokok yang menunjukkan bahwa sekitar $73 \%$ partisipan memiliki teman yang merokok. Tidak hanya perawat yang merokok saja, perawat yang tidak merokok juga berada di dekat perokok dan dapat mempengaruhi kesehatannya.

Analisis uji beda dilakukan untuk mengetahui apakah faktor demografi dari subjek dapat menunjukkan skor yang berbeda dari dimensi-dimensi health locus of control. Hasil menunjukkan pihak yang merokok menentukan skor yang berbeda pada dimensi internal dari health locus of control. Hal ini berarti orang terdekat juga dapat mempengaruhi individu dalam mengambil keputusan untuk dirinya sendiri. Menurut Pinasti (2011), pihakpihak yang mempunyai kekuatan merupakan salah satu yang berperan penting dalam membentuk dimensi internal seorang individu, apabila individu melakukan perilaku yang menyimpang dan tidak mendapatkan respon apapun maka ia 
akan menganggap bahwa perilakunya tersebut tidak akan merugikan orang lain. Sebaliknya, jika individu tersebut mendapatkan respon bahwa perilakunya menyimpang maka individu akan lebih memperhatikan perilaku yang akan ditampilkan ke masyarakat. Tidak hanya berperilaku negatif seperti merokok, dalam menjaga sebuah kesehatan, individu juga memerlukan dukungan dari orang-orang terdekat seperti keluarga, saudara, teman, dan lain lain. Pada penelitian Prarita (2012) menyatakan bahwa individu yang memiliki dukungan sosial yang tinggi akan menjaga kesehatannya dibandingkan dengan individu yang tidak memiliki dukungan sosial.

Hasil lain menggambarkan bahwa terdapat perbedaan skor dalam dimensi chance dari health locus of control jika didasarkan pada jenis kelamin. Adanya perbedaan skor ini dikarenakan laki-laki lebih memiliki keyakinan yang besar bahwa kesehatan mereka ditentukan oleh faktor nasib, keberuntungan atau takdir Allah (Eiser dkk, 1989), sedangkan perempuan menganggap kesehatannya lebih ditentukan oleh orang lain, seperti saat dirinya sedang sakit, ia akan segera melakukan konsultasi kepada dokter (Senjam \& Singh, 2011). Berdasarkan data statistik diketahui bahwa angka harapan hidup perempuan lebih tinggi dibandingkan laki-laki (Fadiha \& Rahmatika, 2013), hal ini dikarenakan perempuan lebih dapat menjaga perilaku sehat dan mengatasi stres yang dialami sehingga memungkinkan mereka untuk hidup lebih lama dibandingkan laki-laki.

Pada penelitian ini, peneliti menyadari bahwa masih memiliki kendala dalam melakukan penelitian, salah satunya adalah sulitnya mendapat sampel perawat yang mau mengakui dan mengisi bahwa mereka adalah perokok. Oleh karena itu, penelitian selanjutnya diharapkan dapat mencari teknik yang tepat untuk mendapatkan data yang baik dengan lebih memperhatikan karakteristik dari sampel penelitian.

\section{SIMPULAN}

Penelitian ini mengeksplorasi perbedaan antara dimensi-dimensi yang terdapat pada health locus of control pada perawat yang merokok dan yang tidak merokok. Hasil menunjukkan bahwa dimensi chance pada health locus of control berbeda antara perawat yang merokok dan yang tidak. Di sisi lain, analisis data menunjukkan bahwa tidak terdapat perbedaan yang signifikan dalam dimensi internal dan powerful others dari health locus of control pada perawat yang merokok dan tidak merokok. Makna dari hasil penelitian adalah bahwa perawat yang merokok memiliki keyakinan yang lebih dibandingkan yang tidak merokok jika kontrol terkait kesehatannya berasal dari luar dirinya, seperti takdir atau keberuntungan. Hal ini membuat mereka meyakini bahwa diri pribadinya bukan menjadi pihak utama yang mengontrol kesehatannya.

\section{SARAN}

Berdasarkan uraian yang dikemukakan pada bagian simpulan penelitian, rekomendasi yang dapat diberikan untuk meningkatkan perilaku sehat pada perawat yang merokok adalah dengan memberikan program untuk meningkatkan kesadaran para perawat tersebut bahwa faktor internal diri yang paling bertanggung jawab untuk mengontrol kesehatan sehingga keinginan untuk memiliki perilaku sehat dapat terbentuk.

\section{DAFTAR PUSTAKA}

Anas, A. (2016). Kenapa banyak wanita muda memilih jadi perokok, ini 5 alasannya. Retrieved from http://citizen6.liputan6.com/read/2541 329/kenapa-banyak-wanita-mudamemilih-jadi-perokok-ini-5-alasannya.

Bennet, P., Moore, L., Norman, P., Murphy, S., \& Smith, T., C. (1997). Health locus of control and value for health in smokers and nonsmokers. Health Psychology, 16(2), 179-182. 
Chotidjah, S. (2012). Pengetahuan tentang rokok, pusat kendali kesehatan eksternal dan perilaku merokok. Jurnal Psikologi, 16(1), 49-56.

Daroji, M., Prabandari S.Y., \& Pramastri, I. (2011). Puskesmas Dalam Promosi Kesehatan Berhenti Merokok Pada Pasien dan Masyarakat. Berita Kedokteran Masyarakat, 27(2), 83-93.

Eiser, J.R., Eiser, C., Gammage, P., \& Morgan, M. (1989). Health locus of control and health beliefs in relation to adolescent smoking. Journal of Psychology, 84(9), 1059-1065.

Fadiha, S. I., \& Rahmatika, R. (2016). Perbedaan health locus of control pada remaja laki-laki dan perempuan. Prosiding Forum Ilmiah Psikologi Indonesia. Jakarta, Indonesia.

Hapsari, M. A. (2013). Perbedaan perilaku merokok pada perawat dan nonperawat di RSUD $d r$. Moewardi (Skripsi). Universitas Sebelas Maret, Surakarta.

Kristiani, N. (2014). Bahaya merokok bagi kesehatan tubuh. Retrieved from http://grosiramazonplus.com/bahayamerokok-bagi-kesehatan-tubuh/.

Mandasari, Y. (2012). Hubungan antara health locus of control pada perilaku asertif pada remaja yang merokok. Retrieved from http://publication.gunadarma.ac.id/bitst ream/123456789/1235/1/10507268.pdf

Nururrahmah. (2014). Pengaruh rokok terhadap kesehatan dan pembentukan karakter manusia. Prosiding Seminar Nasional (pp. 78-84).

Perdana, A. (2010). Rokok, akibat rokok, dan tips berhenti merokok. Retrieved from www.kompasiana.com/andre_manutd/ rokok-akibat-rokok-dan-tips-berhentimerokok_550037a6a333119a7251013 3.

Pinasti, W. (2011). Pengaruh self-efficacy, locus of control dan faktor demografis terhadap kematangan karir mahasiswa UIN Syarif Hidayatullah Jakarta (Skripsi). Universitas Islam Negeri Syarif Hidayatullah, Jakarta.

Pramudiarja, U. (2012). Mahasiswa kedokteran di Yogyakarta banyak yang merokok. Retrieved from http://health.detik.com/read/2012/03/2 2/094538/1874078/763/mahasiswa- kedokteran-di-yogyakarta-banyakyang-merokok.

Putri, D. W. (2015). Pakar: pola pikir dapat kurangi rokok. Retrieved from http://www.republika.co.id/berita/gayahidup/info-sehat/15/06/10/npq7pxpakar-pola-pikir-dapat-kurangi-rokok.

Rahmatika, R. (2017). Psikologi Kesehatan Untuk Kesejahteraan Bangsa. Prosiding Konferensi Nasional III. Jakarta, Indonesia.

Ratna, D. (2016). Jumlah perokok di Indonesia nomor satu di dunia. Retrieved from http://nasional.republika.co.id/berita/n asional/umum/16/05/24/o7og1u282jumlah-perokok-di-indonesia-nomorsatu-dunia.

Rosy \& Esa. (2015). Kawasan bebas rokok akan diberlakukan di semua pusat kesehatan. Retrieved from http://mediamadura.com/kawasanbebas-rokok-akan-diberlakukan-disemua-pusat-kesehatan/.

Saptono, P. (2011). Kemenkes akan larang perokok menjadi tenaga kesehatan. Retrieved from http://www.tcscindonesia.org/kemenkes-akan-larangperokok-jadi-tenaga-kesehatan/.

Santrock, J. W. (2003). Adolescent perkembangan remaja. Jakarta: Erlangga.

Sari, I. F., Dewi, P.A., \& Utami, T. G. (2014). Deskripsi faktor - faktor penyebab perawat tidak menghentikan kebiasaan merokok. JOM PSIK, I(2), 1-8.

Senjam, S., \& Amarjeet, S. (2011). Study of sense of coherence health promoting behavior in north indian student. Indian Journal Medical Research, 134(5), 645-652.

Simanjuntak, H. M. (2015). 51 persen penduduk Indonesia perokok, terbesar di Asia Tenggara. Retrieved from http://www.antaranews.com/berita/478 550/51-persen-penduduk-indonesiaperokok-terbesar-di-asia-tenggara.

Wallston, A. K., Stein, J.M., \& Smith, A.C. (1994). Form C of the MHLC scales : a condition-spesific measure of locus of control. Journal of Personality Assesment, 6(3), 534-553.

Yunita, N. (2009). Faktor-faktor yang mempengaruhi perilaku merokok pada perawat di ruang rawat inap $d r$. 
Esnawan Antariksa (Skripsi).

Universitas Indonesia, Depok. 